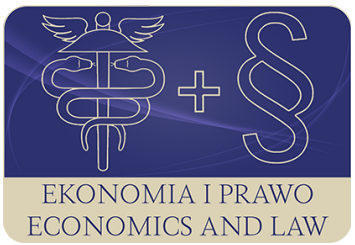

EKONOMIA I PRAWO. ECONOMICS AND LAW

Volume 17, Issue 1, March 2018

p-ISSN 1898-2255, e-ISSN 2392-1625

www.economicsandlaw.pl

EKONOMIA I PRAWO
ECONOMICS AND LAW

ORIGINAL ARTICLE

received 13.06.2017; revised 29.01.2018; accepted 31.03.2018

Citation: Hall, H. (2018). The marketisation of higher education: symptoms, controversies, trends.

Ekonomia i Prawo. Ecomomics and Law, 17(1): 33-42. doi:10.12775/EiP.2018.003.

\title{
The marketisation of higher education: symptoms, controversies, trends
}

\author{
HANNA HALL \\ Rzeszow University of Technology, Faculty of Management, Department of Marketing, \\ al. Powstańców Warszawy 12, 35-959 Rzeszow, Poland \\ $\square$ hhall@prz.edu.pl
}

\begin{abstract}
Motivation: Marketisation of higher education accompanying the development of a market economy having expressed, among others, the 'imitation' of management models specific to the enterprise sector, an adaptation of the market terminology, changing roles of students and the importance of their satisfaction with the study causes still a lot of controversy in the academic community, dividing it into supporters and opponents of the current process with a strong predominance of the first group.

Aim: The aim of this article is to present the arguments and opinions of supporters and opponents (deck research) and the chosen Polish university representatives (primary research) of the marketization process of higher education. In the article the results of desk research as well as the author's own research will be used.

Results: Supporters of marketisation argue that this process will turn universities into more flexible, more efficient and more responsive to the needs of society, the economy, students and parents institutions. Opponents pay attention to the cultural, intellectual and pedagogic consequences of this process. Both groups conclude that there is no turning back from this process and it cannot be avoided. Intensification of university marketing is perceived both by representatives of Polish public and non-public universities, as shown by the research conducted by the author. There were no significant differences in terms

of the statements made by representatives of the different types of universities. Only sometimes more decision-making flexibility of non-public universities was emphasized, better use of information technology in their communication with prospective and current students, better knowledge of IT tools as well as slightly more intensification of promotional activities.
\end{abstract}


Keywords: marketisation of higher education; higher education marketing; changes in higher education marketing

JEL: I23; M39; I29

\section{Introduction}

Since the late 1970s, the culture of academic life in Western countries has undergone some changes. The growing competition in the higher education sector and the fight for students, staff, and financial resources have become a determinant of the marketization process, which is reflected in imitation of business models, an adaptation of market terminology, activity and even aggression in marketing practices (Judson \& Taylor, 2014, p. 51; Williams, 1995, pp. 170-193) of universities as well as in the changing roles of students and the importance of their satisfaction. In Poland this process started much later, which was connected with the development of the market economy in the 1990s.

Especially important for Polish higher education sector in the field of marketisation was the Act of 12 September 1990 on higher education, which allowed the formation of private universities. It influenced (among other factors such as an increase in educational aspirations of young people and a baby boom which lasted until 2002.) on the so-called educational boom which reflected in the increased number of students and the universities. The number of students in Poland increased from 404 thousand in 1990/1991 to 1941 thousand in the peak year 2006/2007 (GUS, 2013). Since then the number has been constantly decreasing. In the academic year 2013/2014 at 434 universities of all types (public 132 with $75.6 \%$ of all students and 302 private) above 1469.4 thousand students were educated (GUS, 2015). The gross enrollment rate, which is a measure of the popularity of education, was rising gradually from $12.9 \%$ in the academic year $1990 / 1991$ to $53.8 \%$ in the academic year $2010 / 2012$, then fell to $48.1 \%$ in the academic year 2013/2014 (net enrollment rates increased respectively from $9.8 \%$ in $1990 / 1991$ to $40.8 \%$ in $2010 / 2011$, and then decreased to $37.8 \%$ in 2014/2015) (GUS, 2015; Hall \& Witek, 2016, pp. 207-208).

The intensification of competition in the higher education sector and the associated intensification of higher education marketization are also influenced by the decline in the number of students at the 'student' age. In 2016, due to demographic decline, 280 thousand students took the final secondary school exam, that is about 20 thousand fewer than in 2015. According to forecasts by sociologists, its apogee is expected in 2020. It is estimated that then the number of secondary school graduates can fall to 200 thousand. According to a report by the Ministry of Science and Higher Education (2013, s. 8), the number of students in the academic year 2022/2023 will be only 1.26 million (a decrease by more than 200,000 in relation to 2013/2014).

The situation of Polish universities, determined by changes in their environment, forces them to look for effective ways to compete for candidates' attention and to attract students in a more effective way than the competitors, which 
implies modeling on market players with experience in this field, i.e. companies using various activities and methods and seeking more and more innovative and effective approaches (Witek \& Hall, 2016, p. 212) to achieve a competitive advantage on a given market.

The specific nature of higher education, and in particular the specific nature of the university, which is education and training, has led to numerous, richly-argued academic discussions related to the adaptation of the above-mentioned business activities and methods.

The aim of this article is to present the arguments and opinions of supporters and opponents (deck research) and the chosen Polish university representatives (primary research) of the marketization process of higher education. In the article the results of desk research as well as the author's own research will be used.

\section{Literature review}

The marketisation of higher education is the process of application of the economic theory of the market to the provision of higher education. The proces seems to be unstoppable (Jones-Devitt \& Samiei, 2011, p. 87). The manifestations of the process of marketization in higher education include the adoption to this sector of relationships and reactions to changes in the environment typical for companies operating in competitive, market conditions.

Institutional rankings and 'league tables' to guide students to choice of university, that devoting increasing energy and resources to marketing, branding and customer service. Much academic research and scholarship is subject to market coordination as is the recruitment and remuneration of academic and other staff (Jones-Devitt \& Samiei, 2011, p. 87).

In academia there is no full acceptance for the process of university marketization and the development of marketing in this sector.

Young (2002) defines a modern university as a bureaucratic machine where there are no teachers and students but 'suppliers' and 'consumers'. As a result, researchers may feel anxious and alienated from students (Gibbs, 2011, s. 52).

Gibbs (2011, p. 52) and Norris (2006, p. 459) are opposed to the growing influence of government and corporations on the higher education sector and the functioning of education under the dictation of the market, conditioned by an economic growth as well as by the expansion of advertising and marketing.

Marketization of university education is also referred to as an 'epidemic' an 'ethical dilemma' (Natale \& Doran, 2012, pp. 187-196) and as a 'paradigm shift' in the area of higher education throughout the western world (Newman \& Jahdi, 2009, pp. 1-11). One of the reasons for the criticism of marketization is the fact that the educational outcomes of students as a result of this process are not improving (Arum \& Roska, 2011). And Molesworth et al. (2009), focus on replacing students' transformations as academics and critical thinkers into students as consumers (Judson \& Taylor, 2014, p. 52). 
In general, according to Judson \& Taylor (2014, p. 52), there is little evidence of the benefits of higher education marketization and the emphasis on student satisfaction except from the short-term financial benefits for universities.

According to Furedi $(2011$, p. 2), in principle there is no objection to universities that compete for funds and sell the results of their research. This is not the root cause of the anxiety associated with the marketization of education.

The anti-marketers vehemently deny that markets and higher education can happily co-exist. For them, the conjunction of higher education and markets are anathema on two grounds - pedagogical and social (Barnett, 2011, pp. 43-45). Furedi (2011, p. 2) adds (in addition to pedagogical) the cultural and intellectual effects of marketization.

The expression of the process is the accompanying adoption of a market-specific terminology, including the controversial use of the educational service term to define the learning process, the suppliers for academic teachers, or the customer (but also the consumer or the product) - to identify the student.

The most anxious effect of marketization is an ability to transform the relationship between researchers and learners into the relationship between a service provider and a customer. The concept of customer, derived from TQM, in relation to a student has even become a kind of a development symbol of higher education market (Furedi, 2011, p. 2). So, that the student may take on some of the characteristics of a customer is not in itself problematic. The point turns on what it means for the student to become a customer. Especially danger is the situation when the student comes to the view that his or her higher education can be bought like any other product or service (Barnett, 2011, p. 46), when the student adopts a 'commodified' view of his or her learning with an eye to the short term (Gibbs, 2008, pp. 269-78), and absolves him or herself from much, if any, involvement in the character of the experience. Nowadays changes of higher education leads to a denial of responsibility on the part of the student (Barnett, 2011, p. 46). According to McMillan and Cheney (1996), a metaphor for student as a customer distracts learners from the role of co-producers of knowledge (Gajda, 2009). It is also not the right approach to focus on a customer satisfaction as the primary goal of the educational process (Molesworth et al., 2011, pp. 149-151).

The student model as a customer, with its striving for customer satisfaction, despite its critique in literature, is a source of numerous benefits to the university. In HE, as in business generally, the relationship between student satisfaction and student retention, progression and graduation has been established (Kara \& de Shields, 2004; Molesworth et al., 2011, p. 145).

Many universities have adopted the student model as a customer, e.g. The 1994 Group has adopted the business idea that 'the customer is always right' and that flattering customers is the right path (Furedi, 2011, p. 3). The presence of a market may lead to a student taking a heightened interest in his or her learning. A market situation might also lead, to a heightened attention to the teaching 
function on the part of the student's lecturers and tutors (Barnett, 2011, pp. 46-47).

\section{Methods}

The aim of the research was to get acquainted with the opinion of university representatives on the marketization process and modern university marketing, their manifestations and perspectives, with particular emphasis on student satisfaction and loyalty. The results of the study presented later in this paper form a part of the author's research on a broader subject range.

The research problem consisted of the following questions:

- Do representatives of the university perceive the intensification of the university marketization process?

- What are the symptoms of the intensification of the university marketization process?

- How do the respondents assess the importance of student satisfaction with a university and what are the ways of its assessment at their universities?

- What methods are used to evaluate the didactic classes and their teachers, including the usefulness and consequences of such research?

- What are the prospects for the development of marketing and university marketization in the next years?

Research carried out by the author were of a qualitative nature and were conducted with an application of In depth Interview method because of the need for full and cogent opinions of the respondents. The research was carried out among 16 representatives of Polish universities chosen by the method of selection of typical units (non-random selection), i.e. among Deputy Chancellors (for marketing and development of the university) or departments managers responsible for marketing of the university. For the study there were selected two (public and private) colleges of 8 Polish cities that are capitals of provinces or districts. As measuring instruments, the study used an interview scenario with an average degree of standardization and a voice recorder. Interviews were carried out at the premises of the universities, in the period from 2015-2016. They lasted between 1.0-2.5 hours, depending on the degree of involvement of the university in marketing activities.

\section{Results}

This part presents the results of the research carried out, including the selected comments from university representatives related to marketization in the higher education sector. The first question asked the representatives of the university concerned the intensification of the university marketization process - does it take place what are its symptoms?

All respondents stated unequivocally that this process was becoming more noticeable and intense and was being observed in many areas of the university. 
Most often, the promotional activities of a university were mentioned, mainly those related to the acquisition of students, but also organizational and product-related (new majors of study) ones. The attention was also paid to the intensification and business aspect (often also referred to as 'unethical' or even 'hysterical') character of competition between universities. Below there are presented five selected statements from university representatives.

- 'We are definitely dealing with the intensification of such activities. First and foremost, it is a very intensive development of promotional activities - PR and e-marketing'. The respondent mentions a dozen or so activities, most of which are related to the Internet, pointing out that there are many more, and adds: 'We keep on observing the market, especially other universities, both public and non-public ones, particularly competing with us in the same thematic area. We are most interested in the new directions and specialties they introduce'.

- 'There is a noticeable intensification of universities activities that are oriented by changes in the environment. These include, among others, organizational changes - a university marketing team has been created, the scope of my duties as a head has increased significantly, and we use many new forms of advertising. Previously, the faculties advertised on their own, depending on their needs. It is now at the university level. Marketing has become much more appreciated by university authorities'.

- 'There is certainly a more intense fight between the universities. It is a pity that this intensification does not concern cooperation'.

- 'Intensification of market-based activities is primarily due to the increased competition in the HEI market, greater awareness of potential customers, greater information needs, but also greater opportunities for low cost and more reliable customer experience. Mostly I mean social media'.

- 'We are creating new majors of study that respond to the interest of contemporary youth - that is the main reason. At the Faculty of Humanities the employers' council has been set up. They will tell us what they expect from graduates'.

Further questions were related to student satisfaction, with particular emphasis on the importance of student satisfaction for a university and the way of its assessment. According to the results of the research, at almost all universities researched there are implemented student satisfaction surveys that use the most common CAI surveys, but also other methods (such as IDI), and they have a very large and even 'strategic' importance.

- 'At our university, a great deal of emphasis is placed on student service. Authorities pay great attention to the service at a very high level. Personnel who does not respect the student was dismissed. Service is for students".

- 'Satisfaction of students is a strategic goal of our university. We conduct satisfaction research using many research methods, including CAWI, FGI. IDI. We also analyze the career of students after graduation'. 
- 'Student satisfaction surveys are implemented systematically with the use of different methods. These are mainly online surveys. These studies are so important that students are forced to do them - they cannot enter the system where they have an electronic index if they do not complete the survey'. One of the most important aspects of student satisfaction is their satisfaction with didactics and relationship with a teacher. The respondents were asked about the research on the evaluation of the didactic classes and their teachers, including the usefulness and consequences of such research. There are presented a few selected statements:

- 'An online survey at the end of the semester, obligatory, filled by all students. Utility? It is obviously high. The conclusions are analyzed after each semester. Students' opinions are taken into account during the employee's periodic assessment. Three-fold negative ratings from students result in a dismissal'.

- 'In addition to conducting surveys, the Rector also meets with student groups. Sometimes he makes an anonymous questionnaire, where students write 'what hurts most', then, sometimes, he appoints a special committee that investigates the matter'.

- 'We do such a survey every semester when it comes to new employees and those who had bad grades before. The rest of the study is in line with the law. The results are, of course very important for the university authorities'.

The last question was about prospects for the development of marketing and university marketization in the next years. None of the respondents had any doubt that the activity of the university in these areas would intensify. In almost all responses, the growing role of the Internet has been emphasized, with particular emphasis on social networking, as well as the ever-widening application of revolutionary information technology.

- 'Certainly, the university activity on the Internet will develop. But in this fight private universities win due to the speed of decision-making and perhaps a little better understanding that we are operating in a very competitive market. These actions will also be more creatively courageous'.

- 'Of course, marketing will play an increasingly important role in university management. In the future, however, it will be mainly on-line marketing'.

- 'The development of marketing at universities is obvious. Certainly more specialized IT tools will be used. The direction of this development will also be determined by the university's internationalization'.

Such studies are carried out at all universities in accordance with the statutory obligation, but they go much further than the statutory guidelines (conducted minimum once per two years). For all universities they are very important, as evidenced by, among others, the dismissal of employees negatively assessed by students. 


\section{Conclusion}

On the basis of the analysis of secondary sources related to the subject as well as from the original research of the author, it can be stated that there is multi-market marketization of higher education. This process is constantly growing and the activities connected with it and the tools applied are increasingly widespread. Despite opposition and criticism of some academic community associated with its negative consequences, there is certainly no retreat from it. The only possible action is mitigation and prevention of negative effects, including: changing the relationship between students and academic teachers based on the relationship between recipients and business donors, or the unreflective pursuit of students satisfaction with didactic classes conditioned by their high grades, their relationship with students or their personality. The pursuit of student satisfaction and its measurement should not raise doubts when taking into account the amount of benefits this phenomenon brings to a university, with particular emphasis on the image of the university and the key role played by students and university graduates in its selection by the candidates for the studies. In the United States, student satisfaction is now the main content of university marketing communications, and is also their main marketing promise. However, one should agree with Mills (2007), that simultaneously maintaining academic standards and striving for customer satisfaction is an extremely difficult requirement. This satisfaction should be provided and measured but in selected areas, not including, for example, the necessary time or engagement to obtain the appropriate level of knowledge and skills or the thematic scope of the implemented modules.

Intensification of university marketing is perceived both by representatives of Polish public and non-public universities, as shown by the research conducted by the author. There were no significant differences in terms of the statements made by representatives of the different types of universities. Only sometimes more decision-making flexibility of non-public universities was emphasized, better use of information technology in their communication with prospective and current students, better knowledge of IT tools as well as slightly more intensification of promotional activities. The attention was also paid to the internationalization of the university, determining the directions of development of modern marketing.

It should be added that in the studies conducted, the identification of students as customers was relatively rare, and was mainly used by non-public university representatives in relation to their students. However, the enormous role of student satisfaction surveys and teacher evaluations at all universities researched and the consequences of this research, e.g. the dismissal of academics who are negatively assessed by students, indicate such a customer approach to the subject. 


\section{References}

Arum, R., \& Roksa, J. (2011). Academically adrift: Limited learning on college campuses. Chicago: The University of Chicago Press.

Barnett, R. (2011). The marketised university: defending the indefensible. In M. Molesworth, R. Scullion, \& E. Nixon (Eds.), The marketisation of higher education and the student as consumer. London \& New York: Routledge Taylor $\&$ Francis Group.

Furedi, F. (2011). Introduction to the marketisation of higher education and the student as consumer. In M. Molesworth, R. Scullion, \& E. Nixon (Eds.), The marketisation of higher education and the student as consumer. London \& New York: Routledge Taylor \& Francis Group.

Gajda, A. (2009). The trials of academe the new era of campus litigation. New York: Harvard University Press.

Gibbs, P., (2011). Adopting consumer time and the marketing of higher education. In M. Molesworth, R. Scullion, \& E. Nixon (Eds.), The marketisation of higher education and the student as consumer. London \& New York: Routledge Taylor \& Francis Group.

Gibbs, P.T. (2008). Marketeers and educationalists - two communities divided by time? International Journal of Educational Management, 22(3). doi:10.1108/09513540810861900.

GUS. (2013). Higher education institutions and their finances in 2012. Retrieved 10.03.2017 from http://stat.gov.pl.

GUS. (2015). Higher education institutions and their finances in 2014. Retrieved 10.03.2017 from http://stat.gov.pl.

Hall, H., \& Witek, L. (2016). Conditions, contemporary importance and prospects of higher education marketing on the example of Polish universities. Procedia Economics and Finance, 39. doi:10.1016/S2212-5671(16)30314-8.

Jones-Devitt, S., \& Samiei, C. (2011). From Accrington Stanley to academia? The use of league tables and student surveys to determine 'quality' in higher education. In M. Molesworth, R. Scullion, \& E. Nixon (Ed.). The marketisation of higher education and the student as consumer. London \& New York: Routledge Taylor \& Francis Group.

Judson, K.M., \& Taylor, S.A. (2014). Moving from marketization to marketing of higher education: the co-creation of value in higher education. Higher Education Studies, 4(1). doi:10.5539/hes.v4nlp51.

Kara, A., \& Shields, O.W. (2004). Business student satisfaction, intentions and retention in higher education: an empirical investigation. Marketing Educator Quarterly, 3.

McMillan, J.J. \& Cheney, G. (1996). The student as consumer: The implications and limitations of a metaphor. Communication Education, 45(1). doi:10.1080/03634529609379028.

Mills, M. (2007). Universities torn between two masters. Retrieved 10.03.2017 from https: / www.timeshighereducation.com. 
Ministry of Science and Higher Education. (2013). Higher education in Poland. Retrieved 10.03.2017 from https://www.nauka.gov.pl.

Molesworth, M., Nixon, E., \& Scullion, R. (2009). Having, being and higher education: The marketisation of the university and the transformation of the student into consumer. Teaching in Higher Education, 14(3). doi:10.1080/13562510902898841.

Natale, S.M., \& Doran, C. (2012). Marketization of education: An ethical dilemma. Journal of Business Ethics, 105(2). doi:10.1007/s10551-011-0958-y.

Newman, S., \& Jahdi, K. (2009). Marketization of education: Marketing, rhetoric, and reality. Journal of Further and Higher Education, 33(1). doi:10.1080/03098770802638226.

Norris, T. (2006). Hannah Arendt and Jean Baudrillard: pedagogy in the consumer society. Studies in Philosophy and Education, 25(6). doi:10.1007/s11217-006-0014-z.

Williams, G. L. (1995). The marketization of higher education: Reforms and potential reforms in higher education finance. In D.D. Dill, \& B. Sporn (Eds.). Emerging patterns of social demand and University reform: Through a glass darkly. Oxford: Pergamon Press.

Witek, L., \& Hall, H. (2016). Prosumption use in creation of cause related marketing programs through crowdsourcing. Procedia Economics and Finance, 39. doi:10.1016/S2212-5671(16)30315-X.

Young, J. (2002). Heidegger's later philosophy. Cambridge: Cambridge University Press.

\section{Acknowledgements}

Author contributions: author has given an approval to the final version of the article.

Funding: this research was fully funded by the Rzeszow University of Technology, Faculty of Management, Department of Marketing statutory sources.

Note: the results of this study were presented at 9th International Conference on Applied Economics Contemporary Issues in Economy (June 22-23, Torun, Poland). 